\title{
Mechanical properties of load bearing walls made of uruguayan hollow ceramic bricks
}

\author{
Características mecánicas de muros fabricados con mampuestos cerámicos huecos uruguayos
}

Juan José Fontana Cabezas (Main and Contact Author) Universidad de la República, Faculty of Architecture Charrúa 2505/101, Montevideo, Uruguay

juanjosefontana@adinet.com.uy

\begin{abstract}
This paper presents an analysis of the mechanical characteristics of masonry walls made of hollow ceramic uruguayan bricks, based on results obtained in laboratory tests that determine the compressive, bending and shear strength of brickwork specimens and the compressive strength of the hollow or perforated bricks used to manufacture them It also discusses the way the specimens fail and the dependence of the masonry walls mechanical strength on the compressive strength of the bricks. A strong relationship between the compressive strength of brickwork specimens tested and the compressive strength of the bricks they were manufactured with, is observed. The equations that best appear to link these two mechanical characteristics, for bricks with compressive strengths up to $25 \mathrm{daN} / \mathrm{cm} 2$, were determined. However, is not observed a direct relation between tested brickwork specimens bending or shear strength, and the compressive strength of the bricks with which they were manufactured. It seems crucial, both in masonry bending and shear strength, the adhesion between ceramic bricks and mortar.
\end{abstract}

Keywords: structures, masonry, hollow ceramic bricks, material testing, mechanical strength.

\section{Introduction}

The housing shortage currently affecting Uruguay and the high costs of the construction industry, make essential the study of economic construction systems capable of ensuring adequate levels of comfort. The qualities of strength, durability, economy, fast construction and insulation that masonry walls made of hollow ceramic bricks have (Mann, 1992), make this material a suitable alternative for the construction of small-scale building structures. However, the use of this structural material in Uruguay has been scarce due to the lack of data on the mechanical characteristics of national bricks, and the absence of standards and regulations adapted to the reality of the local industry (Fontana, 2011). This paper presents and discusses the results of compressive, bending and shear tests of brickwork specimens made of ten types of ceramic hollow uruguayan bricks, and analyzes possible relations between values of masonry mechanical strength and the compressive strength of the bricks with which the masonry was manufactured.

\section{Description Of The Problem}

This paper aims to spread the results of such tests, encouraging the use of ceramic hollow masonry as a structural material in our country. The availability of mechanical strength data will allow a reduction in the safety factors used to calculate structures with this material that, to small-scale buildings, is usually a more economical alternative than reinforced concrete or steel. If the existence of a strong relation between the values of mechanical strength of brickwork specimens and the compressive strength of national bricks with which such prisms are manufactured, is determined, reliable masonry strength values could be estimated from bricks strength values, which are easier to obtain (Lewicki, 1988).

\author{
Manuscript Code: 209 \\ Date of Reception/Acceptance: 01-04-2014 / 01-12-2015.
}

Resumen

Este artículo analiza las características mecánicas de muros fabricados con mampuestos cerámicos huecos uruguayos, basándose en resultados obtenidos en ensayos de laboratorio que determinan la resistencia a compresión, flexión y cortante de prismas de mampostería, y la resistencia a compresión de los mampuestos utilizados para la confección de dichos prismas. Se discuten las formas de rotura de las probetas y se analiza la posible dependencia de los valores de resistencia mecánica de la mampostería hueca de los valores de resistencia a la compresión de los mampuestos con que ésta fue confeccionada. Se observa una fuerte relación entre la resistencia a compresión de los prismas de mampostería ensayados y la resistencia a compresión de los mampuestos con que fueron fabricados y se determinaron las ecuaciones que mejor parecen vincular estas dos características mecánicas, para mampuestos con resistencias a la compresión de hasta 25 daN/cm2. No se observa, sin embargo, una relación directa entre las resistencias a flexión y cortante de los prismas de mampostería ensayados y la resistencia a compresión de los mampuestos con que fueron fabricados. Parecería ser determinante, tanto en la resistencia a flexión como a cortante de la mampostería, la adherencia entre el mortero y los mampuestos.

Palabras Claves: estructuras, mampostería, mampuestos cerámicos huecos, ensayos, características mecánicas.

\section{State Of The Art}

There is no widespread knowledge in Uruguay, about values of mechanical strength of masonry prisms made of ceramic hollow national bricks. No studies have been spread on the relation between the mechanical strength of brickwork specimens and the compressive strength of bricks with which these specimens are made. Spain has done for some time, however, research comparing the compressive strength obtained in ceramic walls experimentally, and analytically from expressions included in European codes (Rolando, 2006).

\section{Metodology}

Ten types of ceramic bricks that fulfilled the following characteristics were selected: be manufactured in Uruguay; have been available for the last two decades, at least, in the Uruguayan construction market; have a percentage of voids higher than 35\%; have dimensions that allow the construction of 12,15 or $20 \mathrm{~cm}$ thick walls, being the most common dimensions in small and medium scale building structures. Bricks with thicknesses of 8,12 and $17 \mathrm{~cm}$ from three manufacturers were selected:

- Manufacturer A: 8-holes hollow brick $12 \times 25 \times 25$, 6-holes hollow brick $17 \times 25 \times 25 \mathrm{~cm}$, and perforated brick $17 \times 25 \times 8 \mathrm{~cm}$.

- Manufacturer B: 6-holes hollow brick $12 \times 25 \times 25 \mathrm{~cm}$, 6-holes hollow brick $12 \times 17 \times 25 \mathrm{~cm}$, and 6 -holes hollow brick $8 \times 14 \times 19$ $\mathrm{cm}$.

- Manufacturer C: 8-holes hollow brick $8 \times 25 \times 25 \mathrm{~cm}, 10$-holes hollow brick $12 \times 25 \times 25 \mathrm{~cm}, 15$-holes hollow brick $17 \times 25 \times 25 \mathrm{~cm}$, and perforated brick $12 \times 17 \times 25 \mathrm{~cm}$.

Through tests of compressive, bending and shear strength of brickwork specimens manufactured with these ten types of ceramic hollow uruguayan bricks, it was determined: 
average and characteristic compressive strength of bricks used in the manufacture of brickwork specimens, average and characteristic compressive strength of brickwork specimens, characteristic flexural strength of brickwork specimens with planes of failure parallel and perpendicular to the bed joints, and average shear strength of brickwork specimens, with and without pre compaction stress.

Due to the absence of uruguayan standards for the study of mechanical properties of ceramic bricks and masonry prisms, spanish standards were chosen because of the influence they usually have on studies of structural materials carried out in Uruguay. Tests were carried out, then, as prescribed in the following standards: Compression tests of bricks: according to UNE-EN 772-1; Compression tests of brickwork specimens: according to UNE-EN 1052-1; Bending tests of brickwork specimens: according to UNE-EN 1052-2; Shear tests of brickwork specimens: according to UNE-EN 1052-3.

The relation between mechanical strength of brickwork specimens and compressive strength of the bricks with which they were manufactured, was finally analyzed. Average and characteristic compressive strength of masonry prisms tested were graphed as functions of the average and characteristic strength of the bricks that compose them, and the equations of the lines that best describe the relation between those strengths were determined with the method of "least-squares". The reliability of these equations was estimated from the coefficient of determination (R2). Equipment used: Gantry crane (756 RC loading cylinder with 75 tons capacity, P 462 model two-speed pump, high pressure hose, regulator valve, check valve and stress gauge); Soiltest CT 711 loading Press (100 tons capacity); laboratory instruments.

\section{Results And Discussion}

\section{Compressive strength of briks}

Average strength, characteristic strength and coefficients of variation are shown in Table 1. Average strength (0) was calculated as the arithmetic mean of six tested hollow bricks, or twenty tested perforated bricks. Characteristic strength (fk) was determined, as prescribed in the standard UNE-EN 772-1, as $\mathrm{fk}=0-1.64 \mathrm{~s}$, being " $\mathrm{s}$ " the standard deviation (Fontana, 2011).

\section{Compressive strength of brickwork specimens}

Perforation pattern of uruguayan hollow bricks do not allow manufacturing walls with horizontal joints of simple execution, when the perforations are placed vertically. It would be necessary to cover the holes in the bottom course to prevent mortar runoff if the bricks are placed in this position, involving work procedures which increase the manufacturing cost. For this reason, brickwork specimens made of hollow bricks were tested with their holes in horizontal direction, as usually are positioned in the local industry. Average strength of hollow bricks with their holes in vertical position is, however, 5 to 10 times higher than strength with holes in horizontal position. In the case of hollow brick $12 \times 25 \times 25$ from B manufacturer, it is about 17 times higher.

Masonry strength depends not only on bricks and mortar strength, but also on factors such as joints thickness (Monteagudo et al., 2015), irregularities in the surfaces, water absorption (Rozo Rincón et al., 2014), maximum mortar aggregate size (Salamanca, 2001), size and pattern of the brick perforations, mortar shrinkage (Mohamad et al., 2009), quality of the workforce, brickwork, and so on (Arredondo, 1956).
Some variables were fixed, therefore, for the construction of the brickwork specimens: brickwork, joints thickness, length and age of the specimens, mortar dosage and operator in charge of the specimens manufacturing.

The use of a single mortar dosage for all specimens was considered desirable in order to compare results obtained with different bricks, despite of wasting mortar strength in the case of prisms made with the weakest bricks (Salamanca, 2001). Dosage selected was: 5 parts sand, 1 part portland cement and $1 / 2$ part hydrated lime.

Average and characteristic strength obtained from brickwork specimens tests (manufactured with holes positioned horizontally, in case of hollow bricks), are shown in Table 2. Average strength $(\mathrm{fm})$ was calculated as the arithmetic mean of five tested specimens. Characteristic strength (fk) was determined, as prescribed in the standard UNE-EN 1052-1, as the lesser of $83,33 \%$ of the average strength ( $\mathrm{fm}$ ) and the lowest value obtained in tests.

Failure mode observed in brickwork specimens manufactured with hollow bricks

Brickwork specimens manufactured with hollow bricks with its holes in horizontal direction, as observed by Oliveira et al. (2006), showed a fragile behavior, collapsing because of local failures before reaching strength values that could compromise the entire specimen. Weaker bricks failed (those who had compromising previous cracks or defects within its mass), causing a rotation of the specimen in its principal plane that led to the general collapse. See Figure 1.

Failure mode observed in brickwork specimens manufactured with perforated bricks

Placing over perforated bricks the horizontal mortar joints, it partially drains into the perforations forming a series of small embeddings. If joints are thick enough, putting the top course will also cause mortar penetration in their brick's holes. The result is a more rigid and monolithic masonry than that made of bricks seated by their flat faces, and therefore, with a more efficient mechanical behavior. Failure mode of prisms made with A manufacturer perforated bricks, resembled that of an homogeneous material under compression: next to failure, material in the middle area was sprayed because of the lateral expansion and tended to remain two triangular pieces in the upper and lower regions of the specimen. See Figure 2.

Specimens made with $\mathrm{C}$ manufacturer perforated bricks had, however, a different behavior. They failed due to lateral tractive force, splitting into two parallel plates by its medium plane. All masonry and all joints were separated into halves. This is different to that observed in the failure of single bricks with which specimens are fabricated. Average compressive strength of mortar used to manufacture these brickwork specimens is lower than average strength of the perforated bricks used to fabricate them. It is expected, therefore, a large transverse strain of the mortar that increases the transverse tractive force on the bricks. These perforated bricks, besides, are weakened in the central area by a large hole, fact that could determine the failure mode of the prisms. If mortar compressive strength increases, additional transverse traction on the perforated bricks will decrease and it will be possible to obtain a higher masonry compressive strength. 


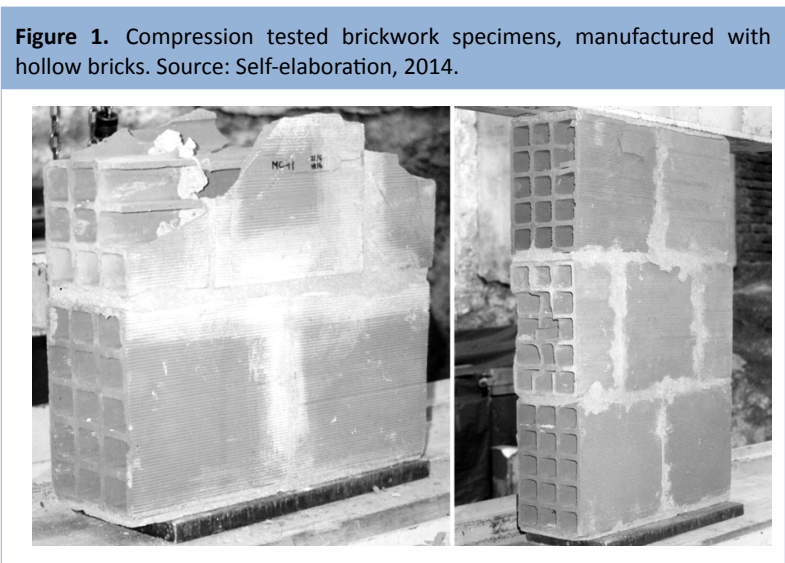

Figure 2. Compression tested brickwork specimens, made with $A$ manufacturer's perforated bricks. Source: Self-elaboration, 2014.

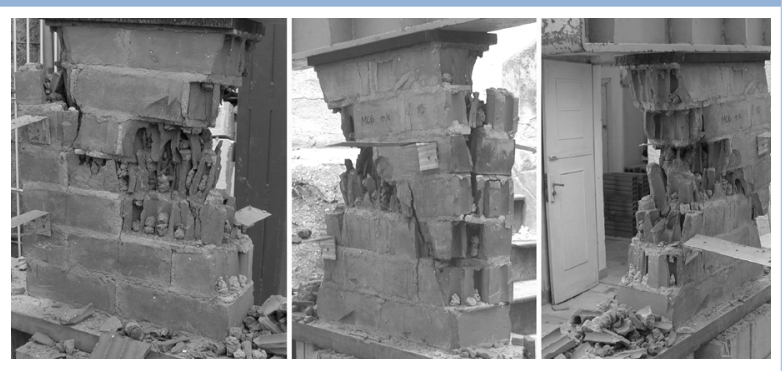

\section{Considerations on the results}

Average and characteristic masonry compressive strength was graphed in relation of average and characteristic bricks compressive strength (hollow bricks positioned with their holes in horizontal direction). A proportional increase in the resistance of masonry is observed, as it increases the resistance of the bricks, with the exception of the results obtained for the $\mathrm{C}$ manufacturer perforated bricks. The line that best represents masonry average strength in relation of hollow bricks average strength, was calculated using the method of "least squares" (see Graph 1):

$$
\mathrm{y}_{1}: \mathrm{R}_{\mathrm{Mm}}=0,9704 \mathrm{R}_{\mathrm{Lm}}-0,5796
$$

The resulting coefficient of determination (R2) is 0,89 . This indicates that $89 \%$ of the values of masonry average strength can be explained by average brick strength. The line that best represents masonry characteristic strength in relation of hollow bricks characteristic strength, was calculated using the method of "least squares" (see Graph 2):

$y_{2}: R_{M k}=0,9787 R_{L k}+0,6096$

The resulting coefficient of determination $\left(R_{2}\right)$ is 0,78 . This indicates that $78 \%$ of the values of masonry characteristic strength can be explained by characteristic brick strength. $\mathrm{RMm}$ : masonry average compressive strength, $\mathrm{R}_{\mathrm{Mk}}$ :masonry characteristic compressive strength, $\mathrm{R}_{\mathrm{Lm}}$ :hollow brick average compressive strength, $R_{L k}$ :hollow brick characteristic compressive strength. Values of perforated bricks compressive strength from A manufacturer, obtained in tests, may be regarded as consistent with values of hollow bricks compressive strength. Not so with values of perforated bricks compressive strength from $C$ manufacturer. The traditionally accepted equations that relate masonry strength $\left(R_{M}\right)$, mortar strength
$\left(R_{m}\right)$ and brick strength $\left(R_{l}\right)$, are those proposed by Haller and Graf (Arredondo, 1956, 392):

Haller equation: $\mathrm{R}_{\mathrm{M}}=\left(\sqrt{1+0,15 R_{l}}-1\right)\left(8+0,057 R_{m}\right) \mathrm{daN} / \mathrm{cm}^{2}$

Graf equation: $\mathrm{R}_{\mathrm{M}}=\frac{R_{l}\left(4+0,1 R_{m}\right)}{16+3(h / d)}+K \quad \mathrm{daN} / \mathrm{cm}^{2}$

$\mathrm{h} / \mathrm{d}=$ height $/$ thickness of the specimen, and $\mathrm{K}=10 \mathrm{Kg} / \mathrm{cm}^{2}$ for a well executed wall, of $1 \mathrm{~cm}$ thick mortar joints; because of manufacturing defects, $\mathrm{K}$ may be smaller or even negative.

Haller and Graf equations were graphed setting the $\mathrm{Rm}$ value as the mean of the average strength obtained for mortars used in the manufacturing of brickwork specimens: $99.6 \mathrm{daN} / \mathrm{cm}^{2}$. In Graf equation, two different values for the ratio $\mathrm{h} / \mathrm{d}$ were considered: 6,5 for specimens made with $12 \mathrm{~cm}$ thick bricks, and 4,6 for specimens made with $17 \mathrm{~cm}$ thick bricks $\left(\mathrm{f}_{\mathrm{G} 12}\right.$ and $f_{G 17}$ equations).We obtain the following equations:

Haller: $(\mathrm{fH}): \mathrm{R}_{\mathrm{M}}=13,68 .\left(\sqrt{1,0,15 R_{l}} \quad 1\right)\left(\mathrm{daN} / \mathrm{cm}^{2}\right)$

Graf: $\left(f_{12}\right): R_{M}=0,3932 R_{l}+10$ and $\left(f_{G 17}\right): R_{M}=0,4685 R_{l}+10$ $\left(\mathrm{daN} / \mathrm{cm}^{2}\right)$

It is noted that equations $\mathrm{y}_{1}$ and $\mathrm{y}_{2}$ determine masonry strength values, in relation of bricks strength values, approximately similar to those that can be determined with Haller or Graf equations, for bricks up to $25 \mathrm{daN} / \mathrm{cm}^{2}$. Out of this environment, $y_{1}$ and $y_{2}$ equations should not be considered reliable. See Graph 3.

Graph 1. Masonry average strength in relation of bricks average strength. Source: Self-elaboration, 2012.

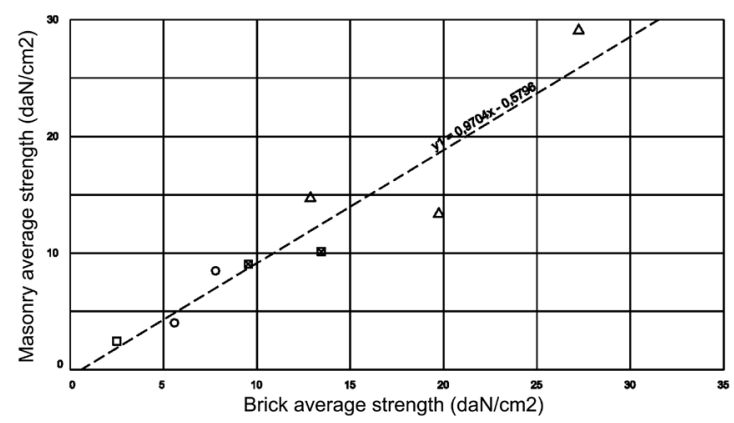

\begin{tabular}{|l|c|c|}
\hline \multirow{2}{*}{ Origin } & \multicolumn{2}{|c|}{ Void ratio (\%) } \\
\cline { 2 - 3 } & $\mathbf{3 5 - 5 0}$ & $\mathbf{5 0 - 6 5}$ \\
\hline A manufacturer & & $\circ$ \\
B manufacturer & $\boldsymbol{\Delta}$ & $\square$ \\
C manufacturer & $\Delta$ & $\Delta$ \\
\hline
\end{tabular}




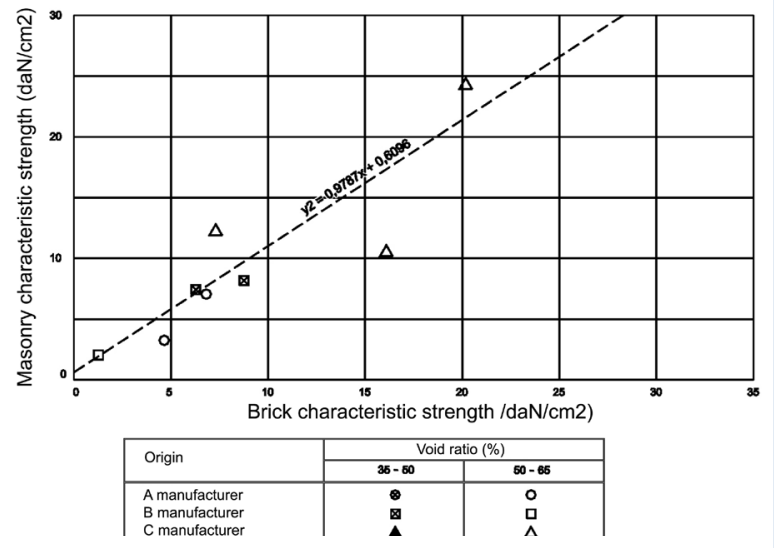

Graph 3. Equations $y_{1}, y_{2}, f_{G 12}, f_{G 17}$ and $f_{H}$. Source: Self-elaboration, 2012.

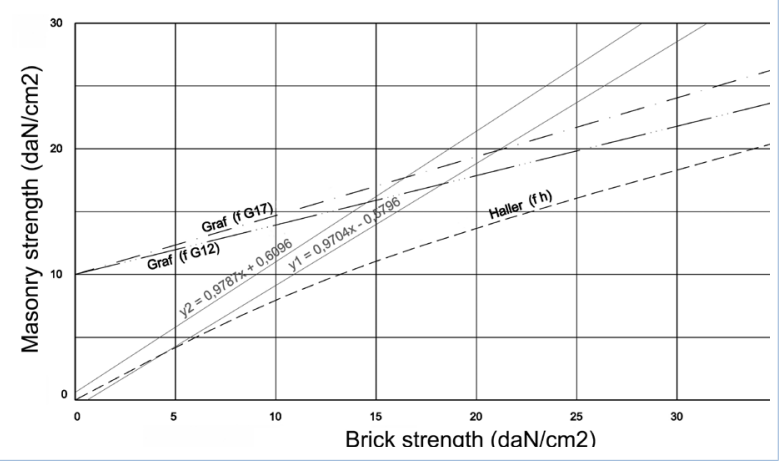

\section{Flexural strength of brickwall specimens}

Values of brickwork specimens characteristic flexural strength, with planes of failure parallel and perpendicular to the bed joints, are shown in Table 3. Average flexural strength $\left(f_{x m}\right)$ is determined as the mean of five specimen test results. Characteristic flexural strength $\left(f_{\mathrm{xk}}\right)$ is determined, as prescribed in the standard UNE-EN $1052-2$, as $66.66 \%$ of the average flexural strength $\left(f_{x m}\right)$.

\section{Failure mode observed in brickwork specimens manufactured with hollow bricks}

Failure in specimens occurs, in all cases, very abruptly and without previous visible cracks. It starts from the tensioned face and quickly spreads to all the section. In specimens tested with planes of failure perpendicular to the bed joints, failure began in the area of adhesion between a vertical mortar joint and a brick, then spreading to adjacent bricks or to other joints. Vertical joints are difficult to execute due to the reduced thickness of the internal partitions that usually hollow bricks have, therefore were found to be the origin of the failure.

In specimens tested with planes of failure parallel to the bed joints, failure always occur in the adhesion between the horizontal mortar joints and bricks.

\section{Failure mode observed in brickwork specimens manufactured with perforated bricks}

Failure of specimens to bending occurred abruptly, without previous visible cracks. Vertical joints do not present manufacturing difficulties such as those originated by hollow bricks holes arranged horizontally. Anyway, failure of specimens tested with planes of failure perpendicular to the bed joints, was originated by adherence problems in such joints or by a brick failure. In specimen MFA02, made with A manufacturer perforated bricks, the adherence in two vertical mortar joints fails and a brick breaks. See figure 3 to the left. Figure 3 to the right shows specimen MFA01 before load was applied.

In all specimens tested with planes of failure parallel to the bed oints, the adherence between mortar and bricks failed. In specimen MFB03, made with A manufacturer perforated bricks, the adherence in a horizontal joint fails. Joints remain attached to the upper and lower bricks after the failure of the mortar embeddings that penetrated into the brick holes. See figure 4 to the left. Failure in specimen MFB01 occurs because of the adherence breacking, in two horizontal and one vertical joint, in stepped form. See figure 4 to the right.

\section{Considerations on the results}

It follows from the results that brickworkspecimen characteristic bending strength is not related to brick compressive strength. Tests results of specimens made with perforated bricks are slightly higher than those of the specimens made with hollow bricks.

It seems determinant of masonry flexural strength, the adherence between mortar and bricks and not their individual strength values. Such adhesion is benefited, in the case of masonry prisms made with perforated bricks, by the embeddings generated when mortar penetrates into the brick vertical holes.

In specimens made with $\mathrm{A}$ and $\mathrm{C}$ manufacturers hollow bricks $17 \times 25 \times 25 \mathrm{~cm}$, the high brick void ratio and the reduced thickness of internal partitions hinder filling vertical joints, and flexural strength, with planes of failure perpendicular to the bed joints, results particularly low.

\section{Shear strength of brickwall specimens}

Average shear strength of brickwork specimens, with and without pre compaction stress, are shown in Table 4. Average shear strength $\left(f_{v m}\right)$ is determined as the mean of nine specimens test results.

It follows from the results that brickwork specimens average shear strength is not related to brick or brickwork specimens compressive strength. Tests results of specimens made with perforated bricks are not higher than those of the specimens made with hollow bricks. It seems determinant of masonry shear strength, the adherence between mortar and bricks, as pointed by Páez-M (2006).

Strength values obtained in specimens made with $A$ manufacturer perforated bricks, were lower than some obtained in specimens made with hollow bricks. However, all specimens made with perforated bricks that were subjected to pre compaction stress, and even some that were not, stayed together after failure. Despite not supporting an increment of load, they did not collapse and the parts that remained after failure, had to be manually separated.

\section{Conclusions and recommendations}

A strong relation between brickwork specimen compressive strength and compressive strength of hollow bricks with which specimens were manufactured, was observed. The equations that best appear to relate these two mechanical characteristics, for bricks with compressive strength values up to $25 \mathrm{daN} / \mathrm{cm}^{2}$, are the equations (1) and (2).

If specimens were fabricated with hollow bricks arranged in vertical direction, masonry compressive strength surely would be much higher than that observed in the tests performed, 
given the observed relationship between the masonry compressive strength and compressive strength of the bricks with which brickwork specimens are made, and since bricks average strength with holes in vertical direction is between 5 and 10 times higher than that measured with holes in horizontal direction.

It is recommended to uruguayan manufacturers, therefore, designing ceramic hollow bricks with which it would be possible to build walls with brick holes in vertical direction. A proper brick design should allow, without altering the percentage of voids, manufacturing horizontal joints without mortar draining inside brick holes, as well as improving thermal and acoustic masonry performance, reducing energy costs (Bustamante et al., 2009).

The size of the central hole and the thickness of the outer partitions of $\mathrm{C}$ manufacturer perforated bricks, appear to be determinants in the failure under compressive strength of brickwork specimens made with these bricks. Redesigning the geometry of the perforations, reducing the dimensions of the central hole and increasing the thickness of the outer partitions, is recommended.

There is no apparent relation between the bending and shear resistance of masonry prisms tested, and the compressive strength of ceramic hollow bricks with which they were manufactured. It seems crucial, both in bending and shear masonry strength, the adhesion between mortar and bricks.
Figure 3. Specimens MFA02 y MFA01. Source: Self-elaboration, 2014.

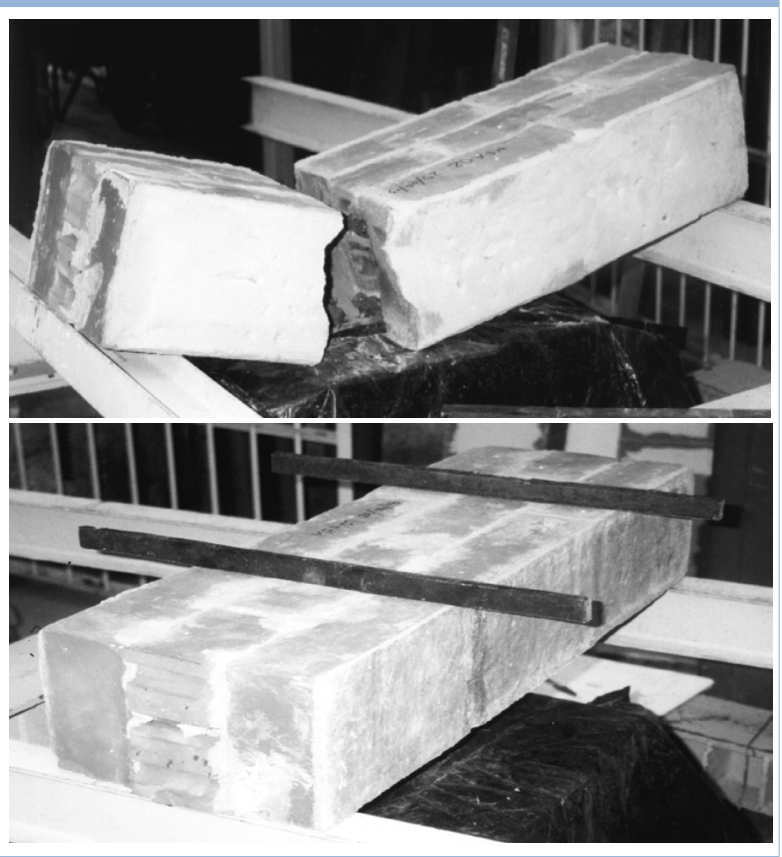

Figure 4. Specimens MFB03 y MFB01. Source: Self-elaboration, 2014.
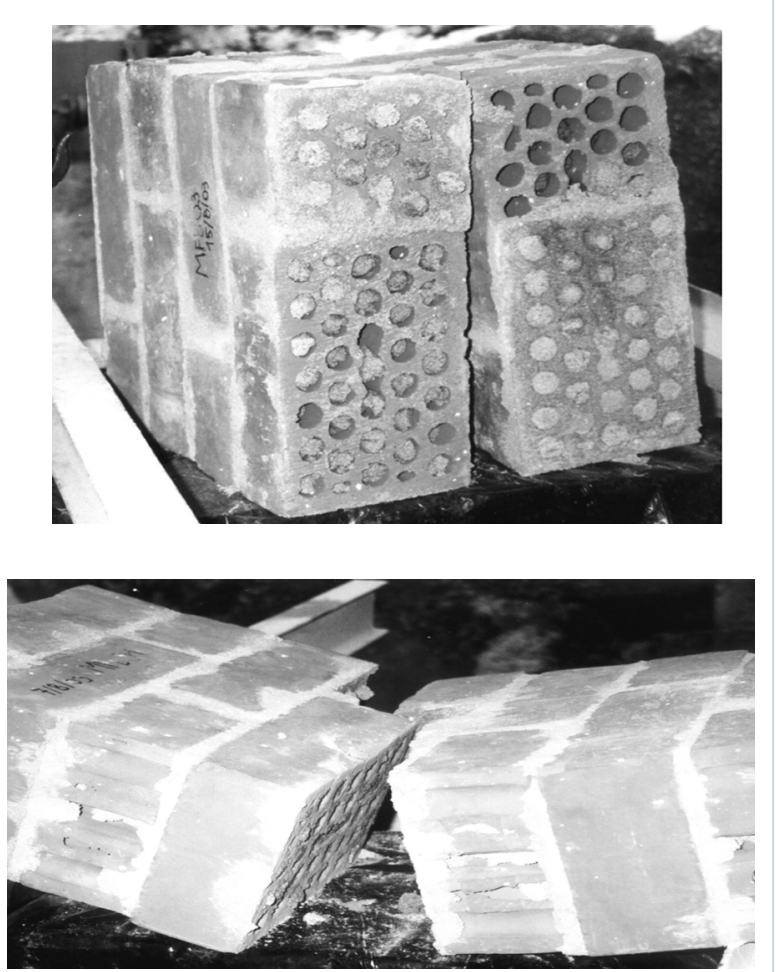
Arredondo, F. (1956). El ladrillo, el mortero y el muro. Revista de Obras públicas, 2895, tomo I, 104.

Bustamante, W., Bobadilla, A., Navarrete, B., Vidal, S., \& Saelzer, G., (2009). Thermal improvement of perforated ceramic bricks. Revista de la Construcción, 8(1), 24-35.

Fontana, J. (2011). Características geométricas, físicas y mecánicas de mampuestos cerámicos huecos fabricados en Uruguay. Ciencia, Docencia y Tecnología, 42, 207-240.

Lewicki, B. (1988). Evaluación de estructuras de muros resistentes. Informes de la Construcción, 40(398), 73-77.

Mann, W. (1992). Avances en la construcción de obras de fábrica. Informes de la Construcción, 44(421), 37-43.

Mohamad, G., Neto, A.B.da S.S., Pelisser, F, Lourenço, P., \& Roman, H. (2009). Caracterização mecânica das argamassas de assentamento para alvenaria estrutural - previsão e modo de ruptura. Matéria, 14(2), 824-844.

Monteagudo, S., Casati, M., \& Gálvez, J. (2015). Influence of the bed joint thickness on the bearing capacity of the brick masonry under compression loading: an ultrasound assessment. Revista de la construcción, 14(1), 9-15.

Oliveira, D., Lourenço, C., \& Roca, C. (2006). Cyclic behaviour of stone and brick masonry under uniaxial compressive loading. Materials and Structures, 39(2), 219-227.

Páez-M, D. (2006). Comportamiento de la mampostería bajo esfuerzos cortantes debido a efectos sísmicos. Revista Ingenierías Universidad de Medellín, 5(8), 91-104.

Reyes, E., Casati M., \& Gálvez. J. (2011). Study of the brickwork masonry cracking with a cohesive fracture model. Materiales de Construcción, 303(61), 431-449.

Rolando, A. (2006). Resistencia característica a compresión de una fábrica de ladrillo en función de la resistencia de sus componentes. Comprobación experimental de expresiones analíticas de la normativa europea. Materiales de Construcción, 283(56), 91-98.

Rozo Rincón, S., Sanchez Molina, J., \& Alvarez Rozo, D. (2014). Propiedades físico mecánicas de bloques $\mathrm{H} 10$ fabricados en el área metropolitana de Cúcuta. Ciencia e Ingeniería Neogranadina, 24(1), 67-78.

Salamanca Correa, R. (2001). La tecnología de los morteros. Ciencia e Ingeniería Neogranadina, 11(1), 41-48. 
Table 1. Compressive strength and coefficients of variation obtained in tests. Source: Self-elaboration, 2014.

Average strength (daN/cm2) - Characteristic strength (daN/cm2) (Coefficient of variation (\%))

\begin{tabular}{|c|c|c|c|}
\hline Brick & $\begin{array}{c}\text { A } \\
\text { Manufacturer }\end{array}$ & $\begin{array}{c}\text { B } \\
\text { Manufacturer }\end{array}$ & $\begin{array}{c}\text { C } \\
\text { Manufacturer }\end{array}$ \\
\hline Hollow bricks $8 \times 25 \times 25$ (vertical holes) & & & $89,61-75,65(9,5)$ \\
\hline Hollow bricks $8 \times 25 \times 25$ (horizontal holes) & & & $27,25-20,18(15,8)$ \\
\hline Hollow bricks $12 \times 25 \times 25$ (vertical holes) & $69,80-12,22(50,3)$ & $41,09-29,43(17,3)$ & $90,39-64,74(17,3)$ \\
\hline Hollow bricks $12 \times 25 X 25$ (horizontal holes) & $7,78-6,81(7,6)$ & $2,49-1,28(29,9)$ & $12,88-7,30(26,4)$ \\
\hline Hollow bricks $17 \times 25 \times 25$ (vertical holes) & $57,58-33,21(25,8)$ & & $95,98-67,49(18,1)$ \\
\hline Hollow bricks $17 \times 25 \times 25$ (horizontal holes) & $5,58-4,65(10,3)$ & & $19,75-16,09(11,3)$ \\
\hline Hollow bricks $12 \times 17 \times 25$ (vertical holes) & & $68,29-52,50(14,1)$ & \\
\hline Hollow bricks $12 \times 17 \times 25$ (horizontal holes) & & $13,45-8,76(21,3)$ & \\
\hline Hollow bricks 9X14X19 (vertical holes) & & $50,19-33,64(20,1)$ & \\
\hline Hollow bricks $9 \times 14 \times 19$ (horizontal holes) & & $9,54-6,28(20,9)$ & \\
\hline Perforated bricks $8 \times 17 \times 25$ & $86,27-54,96(22,1)$ & & \\
\hline Perforated bricks $12 \times 17 \times 25$ & & & $134,81-93,03(18,9)$ \\
\hline \multicolumn{4}{|c|}{ Average strength - characteristic strength of brickwork specimens. fm - fk (daN/cm2) } \\
\hline Brick & A Manufacturer & B Manufacturer & C Manufacturer \\
\hline Hollow bricks $8 \times 25 \times 25$ & & & $29,08-24,23$ \\
\hline Hollow bricks $12 \times 25 \times 25$ & $8,46-7,05$ & $2,42-2,02$ & $14,69-12,15$ \\
\hline Hollow bricks $17 \times 25 \times 25$ & $4,00-3,24$ & & $13,34-10,45$ \\
\hline Hollow bricks $12 \times 17 \times 25$ & & $10,11-8,16$ & \\
\hline Hollow bricks 9X14X19 & & $9,06-7,41$ & \\
\hline Perforated bricks $8 \times 17 \times 25$ & $61,08-50,90$ & & \\
\hline Perforated bricks $12 \times 17 \times 25$ & & & $52,34-43,61$ \\
\hline
\end{tabular}

Table 3. Characteristic flexural strength of brickwall specimens. Source: Self-elaboration, 2014.

\begin{tabular}{|c|c|c|c|c|c|c|}
\hline \multirow[t]{2}{*}{ Brick } & \multicolumn{2}{|c|}{ A manufacturer } & \multicolumn{2}{|c|}{ B manufacturer } & \multicolumn{2}{|c|}{ C manufacturer } \\
\hline & perpendicular & parallel & perpendicular & parallel & perpendicular & parallel \\
\hline Hollow brick $17 \times 25 \times 25$ & 2,57 & 2,77 & & & 2,41 & 2,64 \\
\hline Hollow brick 12X17X25 & & & 3,94 & 2,16 & & \\
\hline Perforated brick 8X17X25 & 5,37 & 2,37 & & & & \\
\hline Perforated brick $12 \times 17 \times 25$ & & & & & & 4,22 \\
\hline
\end{tabular}

